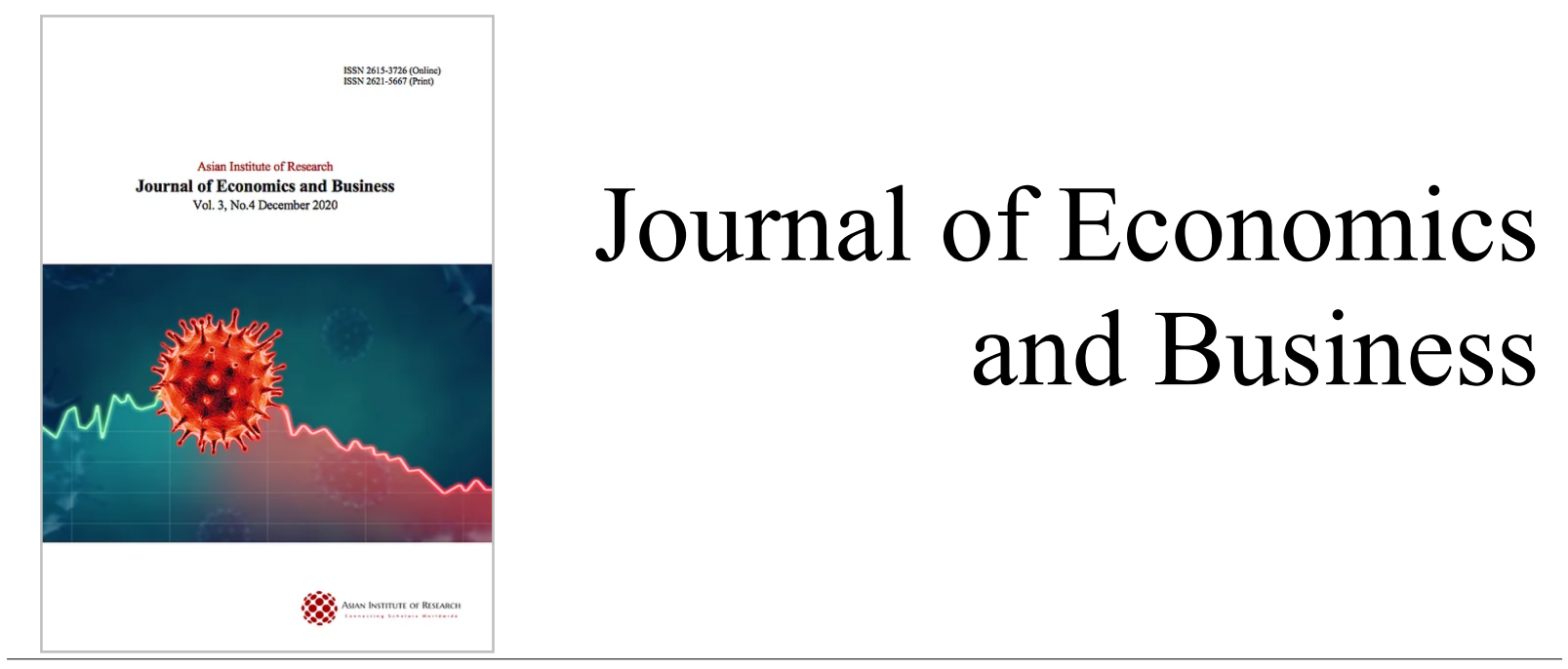

Tjun Tjun, Lauw, and Arsjah, Regina Jansen. (2020), Board Governance, Business Ethics, and Firm Social Responsibility Disclosure. In: Journal of Economics and Business, Vol.3, No.4, 1483-1490.

ISSN 2615-3726

DOI: 10.31014/aior.1992.03.04.295

The online version of this article can be found at: https://www.asianinstituteofresearch.org/

Published by:

The Asian Institute of Research

The Journal of Economics and Business is an Open Access publication. It may be read, copied, and distributed free of charge according to the conditions of the Creative Commons Attribution 4.0 International license.

The Asian Institute of Research Journal of Economics and Business is a peer-reviewed International Journal. The journal covers scholarly articles in the fields of Economics and Business, which includes, but not limited to, Business Economics (Micro and Macro), Finance, Management, Marketing, Business Law, Entrepreneurship, Behavioral and Health Economics, Government Taxation and Regulations, Financial Markets, International Economics, Investment, and Economic Development. As the journal is Open Access, it ensures high visibility and the increase of citations for all research articles published. The Journal of Economics and Business aims to facilitate scholarly work on recent theoretical and practical aspects of Economics and Business. 
The Asian Institute of Research Journal of Economics and Business Vol.3, No.4, 2020: 1483-1490 ISSN 2615-3726

\title{
Board Governance, Business Ethics, and Firm Social Responsibility Disclosure
}

\author{
Lauw Tjun Tjun ${ }^{1}$, Regina Jansen Arsjah²
}

\begin{abstract}
${ }^{1}$ Doctoral student in accounting at Trisakti University, Jakarta, Indonesia. Accounting Department of Economics Faculty, Maranatha Christian University, Bandung, Indonesia. Email: lauwtjuntjun@gmail.com

${ }^{2}$ Faculty of Economics and Business, Trisakti University, Jakarta, Indonesia. Email: regina992001@yahoo.com
\end{abstract}

\begin{abstract}
This paper wants to investigate the impact of board control on social responsibility disclosure. The duration of this study covers three years, i.e., from 2014 until 2016. The population is from public manufacturing companies in Indonesia, and the samples are taken by a simple random sampling method. To analyze the data, the regression model gets used. This research concludes that a positive influence of the supervising board size and the woman portion in this board on the firm social responsibility disclosure is available. Also, business ethics positively affect it.
\end{abstract}

Keywords: Supervising Board Size, Females Becoming Supervisory Board, Ethics, Firm Social Responsibility Disclosure

\section{INTRODUCTION}

According to the stakeholder theory, firms exist to achieve their fund provider interests (stockholders and creditors) and other parties, such as the society around the firms (Ghozali \& Chariri, 2007). Firms with social responsibility will obtain some benefits. They are the increase in market share, the product brand image, and investor magnetism in the capital market (Kotler \& Lee, 2005).

The firms realize that to get attention from the investors related to this social responsibility issue, they have to use their governance devices. One of them gets associated with the role of supervising board (Said, Zainuddin, \& Haron, 2009; Fernandez-Feijoo, Romero, \& Ruiz, 2012; Setó-Pamies, 2013; Zhang, Zhu, \& Dong, 2013; Giannarakis, 2014; Lone, Ali, \& Khan, 2016; Nassem, Riaz, Rehman, Ikram, \& Malik, 2017; Issa \& Fang, 2019; Qa'dan \& Suwaidan, 2019). This role is reflected by the supervising board size [see Said et al. (2009), Lone et al. (2016), Nassem et al. (2017), Qa' dan \& Suwaidan (2019)] and female board portion [see Fernandez-Feijoo et al. (2012), Setó-Pamies (2013), Zhang et al. (2013), Lone et al. (2016), Issa \& Fang (2019)]. 
Fauzan (2011) states the ethical business consideration becomes a motive for the firms to be responsible for society. As declared by Singh \& Prasad (2017), the codes of conduct can be that measurement. However, the research investigating the relationship between ethics measured by these codes and firm social responsibility is infrequent. This situation inspires this study to use business ethics as one of the determinants of company social responsibility besides the supervising board size and female portion becoming this board in Indonesia's public manufacturing companies as an object.

The resource dependence theory explains that a sizeable supervising board number is needed to elevate the company performance because it contains many experts to handle the problems (Pfeffer, 1972). These experts must be having variety in their schooling and understanding of how to perform a responsibility for society (Adam, Almeida, \& Ferreira, 2005). Therefore, the immense size of the supervisory board has a strong relationship with the increasing social responsibility, as shown by the study of Said et al. (2009), Lone et al. (2016), Nassem et al. (2017), as well as Qa'dan \& Suwaidan (2019). Based on this explanation, we form hypothesis one in this manner.

$\mathrm{H}_{1}$ : The big supervising board size stimulates the company to perform societal responsibility.

The presence of women in the supervising board can induce the tendency to disclose more activities related to social responsibility (Bear, Rahman, \& Post, 2010) because of their philanthropy (Ibrahim \& Angelidis, 1994), distinctive leadership type, practiced involvement, various background (Issa \& Fang, 2019). Unlike man, the woman implements her ethical standard more aggressively. She does not tolerate the practice of the opportunistic of managers; therefore, she can effectively increase the monitor on what the managers do, as illuminated by Luo, Xiang, \& Huang (2017). The research conducted by Fernandez-Feijoo et al. (2012), Setó-Pamies (2013), Zhang et al. (2013), Lone et al. (2016), as well as Issa \& Fang (2019) affirms these explanations by displaying a positive influence of the female board on company social responsibility. Based on this explanation, we form hypothesis two in this manner.

$\mathrm{H}_{2}$ : The large portion of the woman becoming a supervising board stimulates the firm to perform societal responsibility.

\section{Business ethics and firm social responsibility}

Business ethics and communal duty are essential to make firms sustainable in the future (Ferrell, Harrison, Ferrell, \& Hair, 2019). Additionally, Fauzan (2011) explains that business ethics is the basis for the firm to realize social responsibility. To act ethically, the firm needs the codes of conduct (Singh \& Prasad, 2017). The survey of Andjarwati \& Budiadi (2008) on the entrepreneurs acting as the manager having a small business in the food industry demonstrates that business ethics positively affects the social firm duty. Similarly, Prasetyono (2011) finds a positive association when investigating public manufacturing firms' secretary perception in Indonesia. Based on this explanation, we form hypothesis three in this manner.

$\mathrm{H}_{3}$ : Business ethics stimulates the firm to perform societal responsibility.

\section{RESEARCH METHOD}

\subsection{The Variables in This Study}

This study has five variables. One of them, the firm social responsibility, functions as an explained variable. The rest, consisting of board governance, business ethics, and company size, performs as an explaining variable.

a. To measure the firm social responsibility disclosure (CSRD), we follow the way utilized by Qa'dan \& Suwaidan (2019). Their research uses 42 required items based on GRI version 4, classified into four information: environment, human resources, communal participation, the goods-and-services given to customers. Furthermore, they divide the total existing items by 42 to measure the disclosure ratio.

b. We measure the board governance by the supervising board size (SBS) by following Said et al. (2009), Giannarakis (2014), Lone et al. (2016), Nassem et al. (2017), Qa'dan \& Suwaidan (2019), Issa \& Fang 
(2019) and the women portion in the supervising board (WBS) by referring to Fernandez-Feijoo et al. (2012), Setó-Pamies (2013), Zhang et al. (2013), Lone et al. (2016), Issa \& Fang (2019), Giannarakis (2014), Nassem et al. (2017), Qa'dan \& Suwaidan (2019).

c. To measure business ethics, we use total conduct codes (CC) disclosed by the firms by denoting Singh \& Prasard (2017). To make the value proportional, we divide the sum of firm statements by the largest number of one firm becoming the sample (see equation 1).

$$
\left.C C E=\frac{\text { Total conduct codes for company }}{\text { The largest number of conduct of company in the sample }} \text {..................(Equation } 1\right)
$$

d. We use the natural logarithm of total assets to measure the company size as the control variable by outlining Ho \& Wong (2001), Cheng \& Courtenay (2006), Said et al. (2009), Setó-Pamies (2013), Giannarakis (2014), Lone et al. (2016), Nassem et al. (2017), and Issa \& Fang (2019).

\subsection{Method to grab the sample}

The research population is public manufacturing firms in Indonesia in 2014, 2015, and 2016. Consistently, 129 firms $(\mathrm{N})$ exist in this period. We use the Slovin formula with a $10 \%$ margin error in equation 2 to get the representing number. This formula is from Suliyanto (2009).

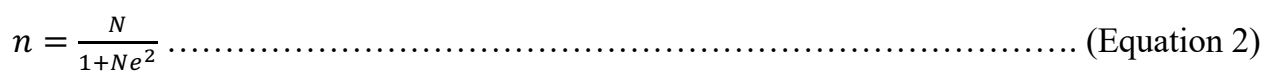

By applying this formula, the number of the represented samples (n) is $\frac{N}{1+N e^{2}}=\frac{129}{1+129(10 \%)(10 \%)}=\frac{129}{2.29}=56.32 \approx$ 56 firms. Furthermore, we work with a simple random sampling method. After grabbing samples, the names of firms are in Appendix 1.

\subsection{Method to analyze the data}

The regression model is used to analyze the data associated with the variables by estimating its coefficient. Furthermore, the intended model exists in equation 3.

$\mathrm{CSRD}_{\text {it }}=\beta_{0}+\beta_{1} \mathrm{SBS}_{\mathrm{it}}+\beta_{2} \mathrm{WBS}_{\mathrm{it}}+\beta_{3} \mathrm{CC}_{\mathrm{it}}+\beta_{4} \mathrm{LN}(\mathrm{TA})_{\mathrm{it}}+\varepsilon_{\mathrm{it}}$ (Equation 3)

\section{RESULT AND DISCUSSION}

\subsection{Descriptive Statistics}

This research has 168 observations, i.e., 56 firms multiplied by three years. Furthermore, the descriptive statistics for all variables can be looked at in Table 1 .

- CSRD has the lowest and highest value of 0.00 and 0.80 , the mean and standard deviation of 0.2042.

- SBS has the lowest and highest value of 2 and 13, the mean and standard deviation of 3.9524 and 1.79757 .

- WBS has the lowest and highest value of 0.00 and 0.67 , the mean and standard deviation of 0.0890 and 0.16309 .

- $\quad \mathrm{CC}$ has the lowest and highest value of 0.00 and 0.67 , the mean and standard deviation of 0.2034 and 0.19759 .

- $\quad \mathrm{LN}(\mathrm{TA})$ has the lowest and highest value of 22.76 and 31.04, the mean and standard deviation of 27.8660 and 1.49847 . 
Table 1. Descriptive Statistics for Research Variables

\begin{tabular}{lccccc}
\hline Variable & $\mathrm{N}$ & Minimum & Maximum & Mean & Standard Deviation \\
\hline CSRD & 168 & 0.00 & 0.80 & 0.2042 & 0.19937 \\
SBS & 168 & 2.00 & 13.00 & 3.9524 & 1.79757 \\
WBS & 168 & 0.00 & 0.67 & 0.0890 & 0.16309 \\
CC & 168 & 0.00 & 0.67 & 0.2034 & 0.19759 \\
LN(TA) & 168 & 22.76 & 31.04 & 27.8660 & 1.49847 \\
\hline
\end{tabular}

Source: Ouput of IBM SPSS 20.

Table 2 displays the regression model estimation based on research variables. SBS, WBS, and COC have a positive coefficient with the probability of the t-statistic of $0.0588,0.0757$, and 0.0810 , separately. Because those values are still below the significance level of $10 \%$, all research hypotheses are not rejected. This circumstance means the big board size, the large portion of the woman becoming a supervising board, business ethics stimulate the company to perform social responsibility.

Table 2. Estimation Result of the Regression Model:

The Determinants of Firm Social Responsibility Disclosure

\begin{tabular}{ccccc}
\hline Variable & Coefficient & Std. Error & t-Statistic & Probability \\
\hline C & -0.914747 & 0.308622 & -2.963970 & 0.0035 \\
SBS & 0.017776 & 0.009341 & 1.902916 & 0.0588 \\
WBS & 0.153928 & 0.086097 & 1.787851 & 0.0757 \\
CC & 0.133513 & 0.076031 & 1.756035 & 0.0810 \\
LN(TA) & 0.036167 & 0.011829 & 3.057486 & 0.0026 \\
\hline
\end{tabular}

Source: Modified Output of E-Views 6.

From the statistical hypothesis testing, it can be inferred some evidence as follows. Firstly, the big supervising board size can stimulate the company to perform societal responsibility. The people becoming the supervisory board are so smart that they can think of the activities needed to serve the firm community obligation. To execute these activities, they need to communicate with top managers. Therefore, these events can be announced in its annual report. Thus, this study confirms the study of Said et al. (2009), Lone et al. (2016), Nassem et al. (2017), and Qa'dan \& Suwaidan (2019).

Secondly, the large portion of the woman becoming a supervising board can stimulate the firm to perform societal responsibility. This situation shows that the females, with her high humanity, can elevate many good relationships with the stakeholders and concern for the community around the firms. Therefore, this study verifies the study of Fernandez-Feijoo et al. (2012), Setó-Pamies (2013), Zhang et al. (2013), Lone et al. (2016), and Issa \& Fang (2019).

Thirdly, business ethics can stimulate the firm to perform societal responsibility. In this research, we use the firm codes of conduct to measure business ethics. These codes are useful as the guidance that managers and employees have to obey and proven as a good proxy because of a positive impact. Therefore, the other researchers can use it in their further investigation. By only considering the positive effect, without the measurement, this study affirms the study of Andjarwati \& Budiadi (2008) and Prasetyono (2011).

By referring to the discussion, this study suggests that firms should have a giant supervising board, not above 13 (see the maximum number of SBS in Table 1), by considering the company size. Besides, the company controlling shareholders can place more females on the supervising board because they care about society. Additionally, the employees and managers must implement the codes of conduct to reflect their care to the community. 


\section{Conclusion}

This research goal is to investigate the influence of the supervising board size, the woman portion in this board, and business ethics on social responsibility disclosure. By utilizing the years 2014, 2015, and 2016 as time observation, 56 manufacturing companies as the sample from the capital market of Indonesia, and the regression model to analyze the data, this study summarizes some evidence.

1. The big supervising board size can stimulate the company to perform societal responsibility.

2. The large portion of the woman becoming a supervising board can stimulate the firm to perform societal responsibility.

3. Business ethics can stimulate the firm to perform societal responsibility.

This study has some boundaries, like the short duration: three years, the utilization of one industry: manufacturing, and the number of determining factors. This situation provides the chance for the next academics to improve them. Firstly, they can add the years as the time observation to be longer, for instance, five or ten years. Secondly, they can occupy firms from non-financial industries so that the conclusion can be extended. Finally, they can augment the determinants by utilizing the outside supervisory board portion, the total audit committee members and board summits, the domestic and foreign institutional possession, managerial ownership, profitability, and leverage.

\section{References}

Adam, R., Almeida, H., \& Ferreira, D. (2005). Powerful CEOs and their impact on corporate governance. Review of Financial Studies, 18(4), 1403-1432.

Andjarwati, A. L., \& Budiadi, H. S. (2008). Pengaruh etika bisnis dan perilaku etis manajer terhadap tanggung jawab perusahaan. Jurnal Bisnis dan Manajemen, 1(1), 1-13.

Bear, S., Rahman, N., \& Post, C. (2010). The impact of board diversity and gender composition on corporate social responsibility and firm reputation. Journal of Business Ethics, 97(2), 207-221.

Cheng, E. C. M., \& Courtenay, S. M. (2006). Board composition, regulatory regime, and voluntary disclosure. The International Journal of Accounting, 41, 262-289.

Fauzan, F. (2011). Corporate social responsibility dan etika bisnis. Modernisasi, 7(2), 115-133.

Fernandez-Feijoo, B., Romero, S., \& Ruiz, S. (2012). Does board gender composition affect corporate social responsibility reporting? International Journal of Business and Social Science, 3(1), 31-38.

Ferrell, O. C., Harrison, D. E., Ferrell, L., \& Hair, J. F. (2019). Business ethics, corporate social responsibility, and brand attitudes: An exploratory study. Journal of Business Research, 95, 491-501.

Ghozali, I. (2016). Aplikasi Analisis Multivariate dengan Program IBM SPSS 23 (8 ed.). Semarang: Badan Penerbit Universitas Diponegoro.

Ghozali, I., \& Chariri, A. (2007). Teori Akuntansi. Semarang: Badan Penerbit Universitas Diponegoro.

Giannarakis, G. (2014). Corporate governance and financial characteristic effects on the extent of corporate social responsibility disclosure. Social Responsibility Journal, 10(4), 569-590.

Ho, S. S. M., \& Wong, K. S. (2001). A study of the relationship between corporate governance structures and the extent of voluntary disclosure. Journal of International Accounting, Auditing, and Taxation, 10, 139156.

Ibrahim, N., \& Angelidis, J. (1994). Effect of board members' gender on corporate social responsiveness orientation. Journal of Applied Business Research, 10(1), 35-40.

Issa, A., \& Fang, H. X. (2019). The impact of board gender diversity on corporate social. Gender in Management: An International Journal, 34(7), 577-605.

Kotler, P., \& Lee, N. (2005). Corporate social responsibility: doing the most good for your company and your case. New Jersey: Jhon Wiley \& Sons, Inc.

Lone, E. J., Ali, A., \& Khan, I. (2016). Corporate governance and corporate social responsibility disclosure: evidence from Pakistan. Social Responsibility Journal, 16(5), 785-797.

Luo, J. H., Xiang, Y., \& Huang, Z. (2017). Female directors and real activities manipulation: evidence from China. China Journal of Accounting Research, 10(2), 141-166.

Nassem, M. A., Riaz, S., Rehman, R. U., Ikram, A., \& Malik, F. (2017). Impact of board characteristics on corporate social responsibility disclosure. The Journal of Applied Business Research, 33(4), 801-810.

Pfeffer, J. (1972). Size and composition of corporate boards of directors: The organization and its environment. Administrative Science Quarterly, 17(2), 218-228. 
Prasetyono, P. (2011). Analisis ukuran perusahaan, penerapan etika bisnis dan praktik corporate governance terhadap penerapan tanggung jawab sosial perusahaan (Studi pada perusahaan manufaktur yang terdaftar di Bursa Efek Indonesia). Seminar Nasional Penelitian dan PKM: Sosial, Ekonomi, dan Humaniora. 2(1), pp. 239-250. Bandung: Universitas Islam Bandung.

Qa' dan, M. B. A., \& Suwaidan, M. S. (2019). Board composition, ownership structure, and corporate social responsibility disclosure: the case of Jordan. Social Responsibility Journal, 15(1), 28-46.

Said, R., Zainuddin, Y. H., \& Haron, H. (2009). The relationship between corporate social responsibility disclosure and corporate governance characteristics in Malaysian public listed companies. Social Responsibility Journal, 5(2), 212-226.

Setó-Pamies, D. (2013). The relationship between women directors and corporate social responsibility. Corporate Social Responsibility and Environmental Management, 22(6), 334-345.

Singh, C., \& Prasad, M. (2017). Code of ethics in an organisation. International Journal of Application or Innovation in Engineering \& Management, 6(5), 138-142.

Zhang, J. Q., Zhu, H., \& Dong, H. B. (2013). Board composition and corporate social responsibility: An empirical Investigation in the post-Sarbanes-Oxley era. Journal of Business Ethics, 114, 381-392. 
Appendix 1 . The name of the samples

\begin{tabular}{|c|c|c|}
\hline No. & Code & The name of the company \\
\hline 1. & BRAM & Indo Kordga Tbk. \\
\hline 2. & GDYR & Goodyear Indonesia Tbk. \\
\hline 3. & INDS & Indospring Tbk. \\
\hline 4. & LPIN & Multi Prima Sejahtera Tbk \\
\hline 5. & MLBI & Multi Bintang Indonesia Tbk. \\
\hline 6. & INAF & Indofarma Tbk. \\
\hline 7. & KAEF & Kimia Farma Tbk \\
\hline 8. & KLBF & Kalbe Farma Tbk \\
\hline 9. & MERK & Merck Tbk. \\
\hline 10. & SIDO & Industri Jamu dan Farmasi Sido Muncul Tbk. \\
\hline 11. & MBTO & Martina Berto Tbk. \\
\hline 12. & TCID & Mandom Indonesia Tbk. \\
\hline 13. & UNVR & Unilever Indonesia Tbk. \\
\hline 14. & CINT & Chitose Internasional Tbk. \\
\hline 15 . & LMPI & Langgeng Makmur Industri Tbk. \\
\hline 16. & INTP & Indocement Tunggal Prakarsa Tbk. \\
\hline 17. & SMCB & Holcim Indonesia Tbk. \\
\hline 18. & WTON & Wijaya Karya Beton Tbk. \\
\hline 19. & AMFG & Asahimas Flat Glass Tbk \\
\hline 20. & ARNA & Arvana Citramulia Tbk. \\
\hline 21. & IKAI & Intikeramik Alamasri Industri Tbk \\
\hline 22. & KIAS & Keramika Indonesia Assosiasi Tbk \\
\hline 23. & MLIA & Mulia Industrindo Tbk. \\
\hline 24. & TOTO & Surya Toto Indonesia Tbk. \\
\hline 25 . & ALKA & Alakasa Industrindo Tbk. \\
\hline 26. & BAJA & Saranacentral Bajatama Tbk. \\
\hline 27. & BTON & Betonjaya Manunggal Tbk. \\
\hline 28. & GDST & Gunawan Dianjaya Steel Tbk \\
\hline 29. & JKSW & Jakarta Kyoei Steel Works Tbk. \\
\hline 30. & JPRS & Jaya Pari Steel Tbk. \\
\hline 31. & LION & Lion Metal Works Tbk. \\
\hline 32. & LMSH & Lionmesh Prima Tbk. \\
\hline 33. & NIKL & Pelat Timah Nugantara Tbk. \\
\hline 34. & PICO & Pelangi Indah Canindo Tbk. \\
\hline 35. & BUDI & Budi Starch \& Sweetener Tbk \\
\hline 36. & DPNS & Duta Pertiwi Nusantara Tbk. \\
\hline 37. & EKAD & Ekadharma International Tbk. \\
\hline 38. & ETWA & Eterindo Wahanatama Tbk. \\
\hline 39. & INCI & Intanwijaya Intemasional Tbk \\
\hline 40. & SRSN & Indo Acidatama Tbk. \\
\hline
\end{tabular}


Appendix l. The name of the samples

\begin{tabular}{|c|l|l|}
\hline No. & Code & The name of the company \\
\hline 41. & TPIA & Chandra Asri Petrochemical Tbk. \\
\hline 42. & UNIC & Ungeul Indah Cahaya Tbk. \\
\hline 43. & AKKU & Alam Karya Ungzul Tbk. \\
\hline 44. & AKPI & Argha Karya Prima Industry Tbk \\
\hline 45. & APLI & Asiaplast Industries Tbk \\
\hline 46. & BRNA & Berlina Tbk. \\
\hline 47. & FPNI & Lotte Chemical Titan Tbk. \\
\hline 48. & IGAR & Champion Pacific Indonesia Tbk. \\
\hline 49. & IMPC & Impack Pratama Industri Tbk. \\
\hline 50. & IPOL & Indopoly Swakarga Industry Tbk. \\
\hline 51. & SIAP & Sekawan Intipratama Tbk \\
\hline 52. & SIMA & Siwani Makmur Tbk. \\
\hline 53. & TALF & Tunas Alfin Tbk. \\
\hline 54. & TRST & Trias Sentosa Tbk. \\
\hline 55. & YPAS & Yanaprima Hastapersada Tbk \\
\hline 56. & CPIN & PT Charoen Pokphand Indonesia Tbk \\
\hline
\end{tabular}

